The Jus Post Bellum and the Responsibility toward Refugees of War

In: Nida-Rümelin, Julian / Daniels, Detlef von / Wloka, Nicole (Hrsg.): Internationale Gerechtigkeit und institutionelle Verantwortung. - ISBN: 978-3-11-061586-9. - Berlin: De Gruyter, 2019.

S. $293-308$

(Forschungsberichte / Interdisziplinäre Arbeitsgruppen, Berlin-Brandenburgische Akademie der Wissenschaften ; 41) 


\section{The Jus Post Bellum and the Responsibility toward Refugees of War}

The philosophical debate on the legitimization of war has a long history. With few exceptions, however, the center of attention has usually been placed on what legitimizes wars (jus ad bellum) and how they may be led (jus in bello). Most theoreticians have not discussed the dimension of the jus post bellum: that wars, just like every other human action, not only have a beginning and are carried out but also have an end and an aftermath and involve responsibility for the consequences of the events. What happens after the war, whether (and which of) the protagonists are liable for the political, institutional and economic reconstruction of the country, whether they carry a responsibility toward the collapsed society, the wounded, those that were left behind or the refugees, these ethically essential questions are usually not taken into consideration. This may be explained by the fact that the problems mentioned, once the war is over, obligate politics and not the conduct of war (and thus no longer the theory of a legitimate war). That such an explanation is wholly inappropriate is not only confirmed by the pragmatic fact that poorly held peace negotiations, unfair treaties and unresolved conflicts may fuel new violent conflicts. It is simply stunning that the consequences of individual and collective actions are considered from ethical as well as legal perspectives as intrinsic components of their legitimization but that the devastating effects of the war are hardly taken into account in the analysis of the war's justness and resulting responsibilities.

In recent decades, the neglected dimension of the jus post bellum has at least received increased attention, particularly as a result of the unresolved conflicts in Afghanistan and Iraq as well as the devastating civil war in Syria (Orend 2012; May 2012). This paper does not aim to discuss the doctrine of the jus post bellum as a whole or to put it into a new perspective. I will focus on a grave consequence of the war and a significant dimension of the post-war period that is unjustly ignored by the relevant theory, namely, the question regarding responsibility and obligation toward refugees, that is, persons who left their country because of the war.

A German version of the text will be published in v. Harbou/Markow (2019). I would like to thank Rüdiger Bittner, Manfred Frank, André Georgi, Frederik v. Harbou, Jaketerina Markow and the participants of the research colloquium practical philosophy in Bielefeld for their important comments and input.

๑ OpenAccess. (C) 2019 Véronique Zanetti, publiziert von De Gruyter. (cc) BY-NC-SA Dieses Werk ist lizenziert unter der Creative Commons Attribution-NonCommercial-ShareAlike 4.0 Lizenz. 
Do those who willfully start a war have a responsibility toward refugees in the form of an obligation that is not already covered by international refugee law ${ }^{1}$ Should the answer be positive, the question then arises whether the initiators of the war are also responsible if the war represents a "just" intervention against a regime that itself has caused streams of refugees due to massive human rights abuses. Underlying this line of thought is the more general question whether the ethics of peace - the reflection on the conditions of its just establishment and the responsibilities for its realization - should be understood as part of the jus post bellum doctrine. The very sketchiness of the doctrine and especially its dependence on other parts of the doctrine of the just war invite skepticism. After the war, one might argue, everything should be done to pacify a conflict permanently. Pragmatism and efficiency, not retributive considerations are then called for. Blaming a certain side for the war does not lead anywhere. Wars are a business in which all involved inevitably get their hands dirty. A final line should be drawn and the focus should be on the future.

Those who think this way consider the obligation to help in the reconstruction effort as a duty of humanity. Accordingly, the doctrine of just war would lose its applicability with the war's end. A jus post bellum would thus be superfluous (Lazar 2012).

This article concentrates on these questions and the desideratum of the literature on the just war. I will distinguish between a minimal and maximal interpretation of the jus post bellum. In addition, I will ask whether the jus post bellum should be conceived in a logical and ethical connection with the jus ad bellum and the jus in bello at all.

I will analyze the arguments that speak for and against treating the dimension of flight from the consequences of war under the rubric of the jus post bellum. I will not argue in favor of a too close connection between the three elements of the doctrine of the just war. Wars, such as defensive war or humanitarian intervention, are not only unjust because the parties involved do not care about the post-war period. And an unjust war does not automatically mean a failure of the jus post bellum. Moreover, the variety of the potential measures for maintaining peace becomes too limited if one focuses solely on the attribution of guilt (Lazar 2012, p. 204). Not only the fighting parties but also countries that are financially better off and have the required competencies should be involved in the reconstruction effort. There is a lot to be said, however, that jus post bellum should not be entirely substituted by an independent doctrine of

1 With respect to the protection of refugees, focus is especially on the Geneva Refugee Convention of 1951 and its additional protocol on the legal status of refugees of 1967. 
peace. The serious consideration of establishing sustainable peace as well as the resulting costs should place high burdens on the decision to use military force. I also advocate the position that part of the responsibilities toward refugees of war are due to the destruction that is inevitably caused by the war. In this sense, all parties involved in the war carry a responsibility insofar as they bring harm to a people (Pattison 2013; Carens 2013, p. 195). ${ }^{2}$ "War matters not only because of the terrible toll it takes on human lives and the environment, but because it is practically the only sphere of human conduct in which we actively aim at such terrible ends - and believe that it might be justified to do so" (Frowe/Lazar 2018, p. 2). This speaks for a jus post bellum. The obligation - I will make a suggestion at the end as to how it could be designed institutionally - should, however, not be understood as punishment but as a form of compensation. Thus, the USA took in hundreds of thousands of refugees from Vietnam, Cambodia and Laos after the Vietnam War - as a gesture of compensation. With reference to the problem of refugees of war, however, I consider it irrelevant who initiated the war or whether the war was just or unjust.

I would like to point out that I do not take up the debate as to whether nations have a general obligation to take in refugees of war and how such an obligation is in agreement with the right to sovereignty. I also do not focus on a duty of humanity toward others (be they next of kin or strangers). I do not deny it, on the contrary. However, my considerations are limited here to aspects of the jus post bellum. The retributive argument does not replace humanitarian responsibility, though. The special responsibility of some nations does not provide others with a blank check to neglect their legal and humanitarian obligations. I am aware of the fact that, as soon as I allow the relationship between the reasons for the flight and the responsibility toward refugees to become normatively relevant I open a Pandora's box: We would have to ask ourselves accordingly why only war but not all other causes for flight, which are also due to the harming of people and unjust global institutions such as global poverty or climate change, are taken into account. Indeed, these aspects would have to be analyzed as well. I will intentionally leave them out here. I solely focus on the context of war, thus on the jus post bellum. As mentioned, it is about a concrete responsibility and not about an obligation of man in general. Since

2 Joseph Carens mentions the causal connection of causing harm as a potential justification for having to take in refugees. 
there is hardly any literature on this question that affects me, I consider this article as a draft to stimulate a debate that is only slowly beginning. ${ }^{3}$

\section{Jus Post Bellum}

The jus post bellum regulates the transition from war to peace and the establishment of a post-war order. Considerations on a just peace are articulated along three axes: compensation for damages; retributive justice, namely, the punishment of war crimes; establishment of institutional conditions of a permanent peace. Although there are different opinions in the literature on how a just post-war state should look like, how it is brought about and which demands are directed at whom, there is broad consensus about some key aspects: namely, that the victorious parties should reestablish the political sovereignty and territorial integrity of the defeated enemy; that the victims of war crimes should be compensated; that the defeated nation and its civil society should be supported in the rebuilding effort and that war criminals should be put on trial (Fabre 2018). Opinions vary significantly when it comes to ascribing responsibilities.

Minimalists consider the jus ad bellum to be a legal instrument of prevention to limit the demands of the victorious parties from the beginning. They distance themselves from the theologically rooted doctrine of the just war and base their position on the legal interpretation as it was provided especially in the $17^{\text {th }}$ and $18^{\text {th }}$ centuries by Hugo Grotius and Emer de Vattel (Bellamy 2008, p. 602). ${ }^{4}$ According to them, those in power may only go to war with the purpose of responding to unjust attacks (de Vattel [1758] 1959). ${ }^{5}$ The jus post bellum was accordingly

3 One of the few exceptions is an article by James Souter, Souter (2014). Carens also mentions compensation as potential justification of a special obligation. However, he does not follow up on this any further: "The first rationale [to generate a duty to admit refugees] is causal connection. Sometimes we have an obligation to admit refugees because the actions of our own state have contributed in some way to the fact that the refugees are no longer safe in their home country" (Carens 2013, p. 195).

4 See Alex Bellamy "Drawing upon the quasi-judicial concept of the just war evident in the work of jurists such as Grotius and Vattel (...), minimalists tend to view just wars in terms of rights vindication and argue that combatants are entitled to wage war only to the point at which their rights are vindicated" (Bellamy 2008, p. 602).

5 War is the state of pursuing the law through violence, says Emer de Vattel ("Der Krieg ist der Zustand der Verfolgung des Rechts durch die Gewalt”, de Vattel [1758] 1959, Chap. I/I). And nations have the right to make use of force only to their defense and protection of their rights (Und das Recht zur Gewaltanwendung steht den Nationen "nur zu ihrer Verteidigung und zur Wahrung ihrer Rechte zu”, de Vattel [1758] 1959, Chap. III/III). 
limited to correcting the wrong that had caused the war. This includes the legal regulation of compensation and restitution of illegally taken goods. Law should prevent that the resulting vacuum of power would be abused by the victorious parties for their own good.

With regard to the question whether nations are only allowed to restore the status quo ante, minimalists respond differently. Some consider the removal of a government that has been viewed as a threat to international peace as a consequent and rightful continuation of the jus ad bellum (Orend 2012, p. 45; Cohen $2006-7$, p. 498). ${ }^{6}$ Strictly speaking, however, regime change does not belong to the legal measures of correcting unlawful behavior; other authors therefore criticize this position as inconsistent (Bellamy 2008, p. 606). On the other hand, the punishment of war criminals is considered to be an important measure in restoring trust in the judicial institutions and the state. In the minimalist interpretation, it is moreover unclear how legal instruments are to function if neither side has a just reason for the war. And if a war was unjust, the minimalist does not have the ability to hold the unjust victor responsible for taking jus post bellum measures.

Maximalists argue that victory does not only entail the obligation to moderate but also to take positive measures towards a sustainable peace and the reestablishment of a functioning constitutional state (Bellamy 2008). The return of stolen goods, compensation for goods that cannot be replaced, rebuilding, reconciliation, are, as already mentioned, measures that, in the view of maximalists, contribute to a just and sustainable peace and therefore belong to the instruments of the jus post bellum. They exist largely independent of the legitimacy or illegitimacy of the war (May 2012, pp. 19-20)

It is astonishing that neither the mainly corrective interpretation of the jus post bellum by the minimalists nor the extended interpretation of the maximalists takes into account the dimension of displacement and flight as one aspect of the consequences of war and responsibility to rebuild.

One reason for this may be the fact that refugees, insofar as they are in exile, are mostly not part of post-war negotiations. This reason is, however, hardly convincing. Displacement and flight are not natural events. People leave their homes during the war because they lost everything in the devastation of the war, because they are afraid of their lives or because they have been intentionally displaced by the government or a war party. Moreover, a large proportion of

6 See Orend, who considers the aim of a just war as to ensure "a more secure possession of our rights, both individual and collective" (Orend 2012, p. 45). Other critics go much further and view the normative standard of interventionist nations to install more just governments as an extension of colonial thought (Cohen 2006-7, p. 498). 
refugees wish to return to their native country. Enabling and preparing their return is often one of the basic preconditions for reviving a broken economy and sustainable peace among a society. ${ }^{7}$ Due to at least these two reasons the aspect of responsibility toward refugees belongs, in my view, to the key questions of the ethics of a just peace - and accordingly, of the jus post bellum. Therefore, one may wonder why it has been totally neglected in the debate.

\section{War Refugees and Their Protection through International Law}

Before I discuss the arguments that speak for or against the reference to refugees in the jus post bellum, two concepts need to be clarified.

First: When I speak of war refugees, I distance myself from a literal interpretation of the Geneva Refugee Convention, which defines refugees as persons that are being pursued for reasons of race, religion, nationality, affiliation with a certain social group or political convictions (Art. 1 Geneva Refugee Convention). This definition is based on individual situations and neglects war as a structural cause for flight. When I speak of refugees, fleeing persons or also displaced persons, I consider these three concepts not only as representing one and the same, but I also limit myself in this context entirely to flight as a consequence of war.

Second, I will not deal with the problem of domestic displacement. Not because I consider it less dramatic, quite the contrary. Those that are forced to flee within their own country are tragically the "poor relatives" of international law (Orchard 2016, p. 604). While international refugees have a right to protection by the Geneva Refugee Convention of 1951 and thus also receive support from the Refugee Agency of the United Nations (UNHCR), it is expected that domestically displaced persons first of all receive support from their native country even though that is oftentimes the cause for their flight. The mandate of the UNHCR usually does not apply to this group which is even larger than that of international refugees.

My focus is solely on international refugees because the principle of sovereignty often serves governments as a pretense to limit access to their territories. This illustrates the dilemma in which the EU finds itself with respect to those member states that close their borders to refugees. In the context of the jus

7 It should, however, not be forgotten that the massive return of refugees can lead to significant problems especially when their flight was due to civil wars, genocide or widespread racism. I thank Rüdiger Bittner for pointing this out. 
post bellum, obligation is being tied to the special responsibility for damage that has been caused, thus responsibility becomes a matter of retributive duties. The duties toward refugees would accordingly fall under the obligations of compensation for damage that has been caused.

Another problem needs to be pointed out: Does the jus post bellum merely create moral or also legal responsibilities? The status of the jus post bellum remains unclear. For some authors, it definitely falls into the realm of morality (Cryer 2012; Walzer 2004, pp. 162-168). For others, it should also entail legal effects that result from legal norms of humanitarian international law, international human rights agreements or international criminal law (Österdahl/van Zadel 2009, p. 175). ${ }^{8}$ In my view, both positions are valid. The jus post bellum is based on a corpus of international law that binds the respective contracting states. The basic principles of the jus post bellum, however, are moral principles that have a regulatory function insofar as they provide information on how international law can be further developed by interpretation or new contracts (May 2012, p. 4). ${ }^{9}$

\section{Responsibilities toward Refugees as Part of the Jus Post Bellum?}

A first argument against integrating a responsibility toward refugees into the doctrine of the jus post bellum could be: We only speak of jus post bellum if the war is over. The refugee problem is one that occurs during the war. After the war, it is only temporary, as long as the rebuilding of the nation has not gone far enough, as long as there is not a minimum of sufficient infrastructure and security.

This argument is of a fundamental nature. It is about clarifying when one can speak appropriately of a "post-war period", as it is in many cases problematic to definitively say when a war is really over. Many conflicts, particularly those that fall under the typology of the so-called new wars, neither have a clearly definable beginning (the war is not "declared") nor a clearly definable end. "Conventional wars" - such as the Gulf War that was declared in 2003 by then US President George W. Bush - also often have an open end: When his suc-

8 Some authors see a quasi-legal set of additional responsibilities in the mandate of aid: The obligation of reconstruction, as declared by the ICISS (Bellamy 2008, p. 616).

9 "In setting out a group of jus post bellum principles I am making a plea for them to become instituted, but my arguments in favor of having them become legal norms should not be confused with thinking that they already have legal status, which they do not” (May 2012, p. 4). 
cessor Barack Obama announced the withdrawal of troops in August 2010, more than 3,000 American soldiers had been called since Bush's proclaimed end of the war (May 2013, p. 316).

The end of military conflict moreover does not necessarily resolve the cause of flight. The reasons for flight are diverse. A continuous lack of security or an ongoing threat for certain groups can be good reasons for granting protection.

The history of wars of the $20^{\text {th }}$ and $21^{\text {st }}$ centuries additionally provides examples for the fact that elements of the doctrine of the jus post bellum indeed have unfolded effectiveness before the war's end. This especially holds for prosecutions of war crimes. The most famous examples are the trials against US Lieutenant William L. Calley, responsible for the My-Lai massacre in the Vietnam War, or more recently, against those responsible for the humiliating abuse in the US-led Abu-Ghraib prison during the Iraq War (May 2012, Chap. 4). ${ }^{10}$ "Efforts at rebuilding civil and political society can be made (...) even as hostilities of insurgent warfare or concerted terrorism continue in ways that can plausibly be said to extend the original war" (Coady 2011, p. 50).

Here one may argue that the realm of the jus post bellum has been left in favor of the jus in bello. It is the task of the judiciary during the war to assess whether the (Geneva) Conventions were adhered to or not.

Regardless of whether the jus in bello is to be understood in close connection to other parts of the doctrine of the just war or not, it is in my opinion appropriate and desirable to never ignore the state after the war in considerations on whether a war or a humanitarian intervention is legitimate and how they are carried out. Already Immanuel Kant stated a warning in his Perpetual Peace as a precondition to a potential peace between governments: "No state at war with another shall allow itself such acts of hostility as would have to make mutual trust impossible during a future peace" (Kant [1795] 1996, p. 320). Thus, he points out that the ways in which a war is conducted, which type of crimes combatants commit or what kinds of weapons are used have a significant effect on peace negotiations and the rebuilding effort after the war. One may only think of the long lasting societal traumatization that results from the systematic practice of rape as an instrument of war (the humiliation of the opposition) as well as the long-term environmental damages from chemical or atom bombs. “(...) States should look not only to the short-term consequences of wartime war crimes trials, but also to the longer-term issue of what the society will be like at the end of

10 In both cases, prosecutions were carried out before US military courts. It is, however, not a requirement of retributive justice that war crimes are tried before an international tribunal (May 2013, Chap. 4). 
war if that war has been conducted in a way that involves war crimes. This raises Jus post bellum issues (...)” (May 2012, p. 73).

If one took the perspective of the jus post bellum seriously, then governments would have to assess, from the perspective of how things would look like after the war, whether it is worth to conduct the war in the first place. "[S]ome serious planning must go into the post-war phase right from the start. Winners, like the United States over Iraq in 2003, should never find themselves in a position where they have won the war but they do not know what to do now, and so start making up post-war policy on the fly" (Orend 2008, p. 40). This, however, does not mean that wars that are indeed legitimate automatically become delegitimized if no one has an idea of what should happen after the war.

There is another pressing question: Should all parties that have initiated a war be held responsible for the admission or financing of refugees (I will turn to this alternative briefly)? Even if a war was begun for humanitarian reasons? As a reminder: I argued in favor of the special responsibility toward refugees due to the harm caused and I am therefore inclined to answer positively. A counter argument would be: The retributive response is first of all conceptualized in a wrong way, it is secondly unfair and bears unintended consequences.

Regarding the first point: The response is wrongly conceptualized because it accuses the wrong side. Not those that carry out a humanitarian intervention violate negative rights, but those in power that caused the intervention by allowing or even organizing the violation of human rights.

This argument holds true. A police operation in response to a bank robbery, the allowed high speed of an ambulance or a fire truck etc. entail risks that we have to take in order for rapid help to be available. Help in reaction to an emergency or damage should therefore not be conceptualized as damage, not even if it results in "collateral damage" as long as it is not the means to realize the end but rather a side effect and is proportionate. However, even if the act, the goal of which is to rescue or aid cannot be considered as damaging - in spite of the fact that innocent people may be harmed by it - this does not mean that the victims have no claim to compensation. Violence in cases of self-defense and helping someone should only be directed at the attacker. It is not allowed to impact the legal interests of third parties as long as there is no state of emergency. If someone uninvolved is harmed by a police operation, he or she has the right to receive compensation (Lazar 2012, p. 208; Tracy 2007, pp. 16-19).

The second argument claims that the retributive perspective entails unjust consequences: “[C]onsistently pursued, rectificatory post-war policies would lead to crippling burdens on both just and unjust belligerents" (Lazar 2012, p. 207). Anxiety toward such "crippling burdens" is appropriate especially if one considers the other responsibilities that go hand in hand with maximalist 
theory of the jus post bellum. The rebuilding of a destroyed nation and its institutions results in gigantic costs. If one were to consequently extend the retributive logic to these areas, the burdens would indeed be crippling and would also affect the wrong people: citizens of a country would be collectively held accountable, regardless of whether the war was legitimate or not. If it was legitimate, they would illegitimately be punished for the costs of a just action. If the war was illegitimate, the citizens would be doubly punished: for an unjust regime and for the consequences of the war led or caused by that regime.

I do not deny that both arguments have a point but would like to highlight three further aspects.

The first refers to the function of the three parts of the doctrine of the just war. The legitimacy of a humanitarian intervention depends both on reasons for going to war and on the way war is led. The literature acknowledges that a military intervention is justified only in reaction to massive human rights violations, i.e., massacres, forced relocation or displacement of a significant part of the population, "ethnic cleansing" or persecution of minorities. The paradox of such an intervention - namely, harming innocent people in the name of defending human rights - is supposed to be less acute due to the fact that attacks are prohibited if they may be "expected to cause incidental loss of civilian life, injury to civilians, damage to civilian objects, or a combination thereof, which would be excessive in relation to the concrete and direct military advantage anticipated". ${ }^{11}$ If the intervention is launched without a clear pathway to success and if it can only be successful by aerial bombardment that threatens non-military targets, it is prohibited.

Starting a war is undoubtedly one of the riskiest endeavors of all. Therefore, there should be high standards regarding the calculation of costs and benefits, and the party leading the war should be held accountable for consequences it did not aim for but the risk of which it could have anticipated (Stoecker 2004, p. 171).

However, these boundaries remain vague and they are morally questionable to the extent that they legitimate the use of military force. ${ }^{12}$ The principles of the jus post bellum provide an opportunity to sharpen these criteria. If one takes them seriously, those who start a war must participate in rebuilding the damaged country. "There are jus post bellum duties on both sides at the end of a war. If the victorious party is the party that justly initiated war, then it may have duties to

11 Protocol Additional to the Geneva Conventions of 12 August 1949, and relating to the Protection of Victims of International Armed Conflicts (Protocol I), 8 June 1977 Art. 51 § 5b.

12 For an illuminating discussion on the principles legitimizing humanitarian intervention, see Merkel (2012). 
rebuild and reconcile, etc.; and the losing side which was the aggressor also obviously has duties at the end of war" (May 2012, p. 16). Accordingly, no government would theoretically be allowed to enter military action which can be estimated to destroy the infrastructure of the opponent and either kill or displace numerous civilians. The responsibility toward refugees of war should also influence the way the war is conducted and provide a strong incentive to create a minimum of collateral damage. If an intervention is successful in achieving its goal, the number of refugees should moreover decrease and not increase.

The second aspect has to do with the logic of a humanitarian intervention. As it is widely known, such an intervention is supposed to protect people from the abuse of power of their own government. This justification rests on the liberal notion dating back to the early modern period which claims that states or governments are justified in exerting their monopoly of violence to protect their citizens. In turn, this means that a state that has become an instrument of repression against its own citizens has lost its legitimacy. Internally, it no longer deserves to be defended by its own people and has consequently forfeited the normative basis of the people's obligation for defense. Externally, it loses its entitlement to recognition of its right to self-defense against other countries.

This opinion has meanwhile even made its way into international law. The concept of "Responsibility to Protect" (or "R2P"), which was particularly shaped by the "International Commission on Intervention and State Sovereignty" (ICISS) ${ }^{13}$ around the change of the millennium, indeed emphasizes the double responsibility that the concept of sovereignty entails: a responsibility directed toward the outside, namely, respecting the sovereignty of other nations, and a responsibility directed toward the inside, namely, protecting the fundamental rights of all citizens within the territory. If a state is not willing or not able to do so, it loses its right to be considered sovereign by the international community. Moreover, it should then be left to the international community to take on a subsidiary responsibility toward the people that are being threatened.

By admitting or financially supporting refugees from the country in which the intervention takes place, the intervening countries pursue their declared objectives: they offer protection. In individual cases, they even provide a replacement for the lost political status by granting refugees citizenship. ${ }^{14}$ This demonstrates, one might argue, a test of motivation: why should states that truly care about the protection of strangers, even at the cost of human loss among its own

13 International Commission on Intervention and State Sovereignty (ICISS).

14 On this see the article by James Souter who strongly advocates naturalization of war refugees as a gesture of compensation for a war: Souter (2014). 
people and enormous financial costs as a result of the war, close their borders to refugees of war? In comparison to the overall costs of the intervention (including the costs for its own internal political stability), a contribution to solving refugee crises is relatively small but can have long-term economic benefits (D'Albis/Boutane/Coulibaly 2018).

Finally, it should be pointed out that international law only allows interventions that have been authorized by the UN. Unilateral interventions are in violation of international law. Since the international community has the responsibility to protect, this means that the very same community is liable for upholding the principles of the jus post bellum. Thus, the responsibilities would not be any different than they are now if the organization and costs of the refugee program would be added to the other principles of the jus post bellum. The UNHCR has already taken over a major part of refugee aid worldwide.

Those who are skeptical with respect to the jus post bellum as a legal instrument of peace will raise further doubts. They will, for example, claim that wars create chaotic conflict situations in which several actors are involved. It is often unclear who started a violent conflict or is otherwise responsible. In addition, war crimes are often committed by all parties involved. ${ }^{15}$

This skepticism is appropriate. Due to the just mentioned reasons, among others, I suggested to make no difference between the parties involved in the war. The killing of civilians and the destruction of their livelihood is pro tanto morally condemnable. Refugees of war are victims of violence, be it conducted by an unjust regime, by freedom fighters or intervening troops.

Finally, these skeptics will argue that what matters after the war is to fight suffering quickly and efficiently. The wealthier countries should contribute. This position is de facto not in conflict with the one I have taken. Saudi Arabia as a rich nation should contribute a much larger amount to the UNHCR than, for example, Yemen. The additional amount that Saudi Arabia would need to pay due to the devastating consequences of its military intervention in Yemen, including the flight of civilians, could benefit the UNHCR.

This consideration brings me to the final aspect of the jus post bellum that I would like to mention, namely, its institutionalization. I will limit myself to pro-

15 The question according to Seth Lazar is "whether the harms suffered in war should be treated under the corrective justice rubric at all. Appeals to corrective justice might make sense in peacetime, when the harms are of limited magnitude and the liable party can - with the aid of a careful judicial process - be ascertained. But in the aftermath of wars, when the suffering and wrongdoing are so widespread and general, a focus on compensation should be at best a subordinate goal to the overriding imperatives of reconstruction and peace building" (Lazar 2012, p. 207). 
viding indications into which directions this aspect would need to be developed further.

\section{The Institutional Dimension}

One basic question still remains open: What kind of responsibility toward refugees is at issue? Should governments involved in war be made responsible to admit refugees of a defeated country or of a country in which they have intervened? The generalization of this condition would have absurd consequences. It would seem absurd to force a hostile state to admit refugees as well as to convince them to seek protection in that country. Who among the Syrian victims of Russian bombs would wish to be taken in by Russia? It should rather be left to the refugees in which country they would like to seek asylum.

Currently, the UNHCR is mainly being funded by voluntary contributions of governments, intergovernmental actors, foundations and private persons. It is, however, hard to understand why an organization that serves an indispensable purpose for the international community depends so strongly on the good will of the states. At the latest since the ICISS document on the responsibility to protect was recognized at the UN World Summit 2005 by numerous states - even though not in form of a binding declaration - the protection of civilians in armed conflicts can be considered an acknowledged duty of the international community.

Ideally, all states would have to pay into a refugee fund proportional to their gross national product as well as inversely proportional to the number of admitted refugees. States that already admit a larger number of refugees than on average would need to be relieved or freed with respect to their contribution. States that cause the flight of civilians due to violent politics of a war should be held accountable in a stronger way, either by taking in refugees of war or by paying more. The calculation of the additional financial contribution should be done by an expert commission. The financial participation of private persons and enterprises, which are especially involved in providing war material, or of warlords, who cash in on the war, should not be excluded from the beginning (Kyriakakis 2012, p. 115; Bush 2009; Punch 2009).

\section{Conclusion}

In this article, I pointed out a gap in the jus post bellum and peace research. Flight is an inevitable consequence of all wars. One war dead is matched by hundreds of displaced people. Still, and in spite of the fact that displaced people 
play a significant role in the peace process, they represent the blind spot of research. Refugees of war are treated as part of the ever increasing number of those seeking sanctuary whose rights are protected by the Geneva Refugee Convention. Whether countries have a special responsibility due to their involvement in the war or their contribution to causing flight is, however, seldom discussed.

In this article, I suggested admitting refugees of war into the doctrine of the jus post bellum. This position is supported by the fact that flight is so clearly linked to the damage done by war. This is more so than in other cases where damage is done to persons, such as climate change or unjustness as a result of the global economic system. Wars are prepared. They require long-term financial and logistical planning, especially in the case of intergovernmental wars. In the so-called new wars, where beginning, course and end have very vague contours, identifiable actors are involved as well. In case there is a clear and undeniable responsibility for displacement, these actors, just like in civil law or administrative law, should be obligated to grant refugees sanctuary and/or pay an additional amount of money into an international fund for refugees. The liability for compensation, however, does not mitigate the moral responsibility of other countries to grant refugees of war asylum.

I question the close linkage between the three parts of the theory of the just war: Not only unjust aggressors need to be held accountable for damages caused in a war. However, I do not agree with those who would like to see the ethics of peace building as an independent field. I share the wide spread intuition that causing harm, aside from the moral obligation, imposes a special responsibility upon actors which they otherwise would not have.

Finally, I would like to briefly focus on an argument that refers to the concept of prevention. It claims that responsibilities that are tied to consequences of war could discourage humanitarian interventions. Even if that turned out to be correct, it is in my opinion not decisive. A humanitarian intervention aims at providing help for persons in dire need. It is therefore part of the humanitarian logic to make sure that the endangered persons are protected in a sustainable manner. The willingness to grant them sanctuary and asylum can be understood as a litmus test for the motivation underlying the intervention. Should the responsibility of the parties involved in the war as well as of the international community to reestablish a just peace make armed conflicts more difficult, the better.

\section{Bibliography}

Bellamy, Alex (2008): “The Responsibilities of Victory: Jus Post Bellum and the Just war”. In: Review of International Studies 34, pp. 601-625. 
Bush, Jonathan (2009): "The Prehistory of Corporations and Conspiracy in International Criminal Law: What Nuremberg Really Said”. In: Columbia Law Review 109, pp. 1094-1262.

Carens, Joseph (2013): The Ethics of Immigration. Oxford: Oxford University Press.

Coady, C.A.J (2011): “The Jus Post Bellum”. In: J. Wolfendale/P. Tripodi (Eds.): New Wars and New Soldiers: Military Ethics in the Contemporary World. Burlington, pp. 49-68.

Cohen, Jean (2006-7): “The Role of International Law in Post-conflict Constitution-making: Toward a Jus Post Bellum for 'Interim Occupations'”. In: New York Law School Law Review 51, pp. 498-532.

Cryer, Robert (2012): “Law and the Jus Post Bellum: Counseling Caution”. In: Larry May/ Andrew Forcehimes (Eds.): Morality, Jus Post Bellum, and International Law. Cambridge: Cambridge University Press, pp. 223-249.

D’Albis, Hippolyte/Boubtane, Ekrame/Coulibaly, Dramane (2018): “Macroeconomic Evidence Suggests that Asylum Seekers Are Not a 'Burden' for Western European Countries”. In: Science Advances 4, pp. 1-5.

Fabre, Cécile (2018): “War's Aftermath and the Ethics of War”. In: Seth Lazar/Helen Frowe (Eds.): The Oxford Handbook of Ethics of War. Oxford: Oxford University Press, pp. 505-518.

Frowe, Helen/Lazer, Seth (2018): “The Ethics of War, Overview”. In: Seth Lazar/Helen Frowe (Eds.): The Oxford Handbook of Ethics of War. Oxford: Oxford University Press, pp. 1-17.

v. Harbou, Frederik/Markow, Jeka (Eds.) (2019): Philosophie des Migrationsrechts. Tübingen: Mohr Siebeck.

International Commission on Intervention and State Sovereignty (ICISS) (2001): The Responsibility to Protect: Report of the International Commission on Intervention and State Sovereignty. Ottawa: International Development Research Centre.

Kant, Immanuel (1996): “Toward Perpetual Peace” [First ed. 1795]. In: Practical Philosophy. Mary J. Gregor (Transl. and ed.). Cambridge: Cambridge University Press, pp. 311-351.

Kyriakakis, Joanna (2012): "Justice after War: Economic Actors, Economic Crimes, and the Moral Imperative for Accountability after War”. In: Larry May (Ed.): Morality, Jus Post Bellum, and International Law. Cambridge: Cambridge University Press, pp. 113-138.

Lazar, Seth (2012): "Skepticism about Jus Post Bellum”. In: Larry May/Andrew Forcehimes (Eds.): Morality, Jus Post Bellum, and International Law. Cambridge: Cambridge University Press, pp. 204-222.

May, Larry (2012): After War Ends. A Philosophical Perspective. Cambridge: Cambridge University Press.

May, Larry (2013): “Jus Post Bellum Proportionality and the Fog of War". In: The European Journal of International Law 24. No. 1, pp. 315-333.

Merkel, Reinhard (2012): “Kollaterale Tötung von Zivilisten”. In: Juristen Zeitung 23, pp. 1137-1192.

Orchard, Phil (2016): “Responding to Forced Displacement as a Mass Atrocity Crime”. In: A.J. Bellamy/T. Dunne (Eds.): The Oxford Handbook of the Responsibility to Protect. Oxford: Oxford University Press, pp. 604-619.

Orend, Briand (2008): “A Just War Theory Perspective”. In: Carsten Stahn/Jann K. Kleffner (Eds.): Jus Post Bellum. Towards a Law of Transition from Conflict to Peace. Cambridge: Cambrige Universtity Press, pp. 31-52. 
Orend, Briand (2012): “Justice after War”. In: Ethics and International Affairs. 16. No. 1, pp. $43-56$.

Österdahl, Inger/van Zadel, Esther (2009): "What Will Jus Post Bellum Mean? Of New Wine and Old Bottles". In: Journal of Conflict and Security Law 14, pp. 175-207.

Pattison, James (2013): “Jus Post Bellum and the Responsibility to Rebuild”. In: British Journal of Political Science 45, pp. 635-661.

Punch, Maurice (2009): "Why Corporations Kill and Get Away With It: The Failure of Law to Cope with Crime in Organizations". In: André Nolkaemper/Harmen van der Wilt (Eds.): System Criminality in International Law. Cambridge: Cambridge University Press, pp. 42-68.

Souter, James (2014): "Durable Solutions as Reparation for the Unjust Harms of Displacement: Who Owes What to Refugees". In: Journal of Refugee Studies 27, pp. 171-190.

Stöcker, Ralf (2004): “Intervention und Einmischung”. In: Georg Meggle (Ed.): Humanitäre Interventionsethik. Paderborn: Mentis, pp. 147-180.

Tracy, Jonathan (2007): “Responsibility to Pay: Compensating Civilian Casualties of War”. In: Human Rights Brief 15. No. 1, pp. 16-19.

Vattel, Emer de (1959) [1758]: "Le droit des gens ou principes de la loi naturelle, appliqués à la conduite des nations et des souverains”. Vol. 3. In: Walter Schätzel (Ed.): Die Klassiker des Völkerrechts in modernen deutschen Übersetzungen. German translation by Wilhelm Euler and Paul Guggenheim. Tübingen: J.C.B. Mohr (Siebeck).

Walzer, Michael (2004): Arguing About War. London: New Haven. 